\title{
An Insight to Automation \& Digitalization of Retail Stores
}

\section{S.Akhila}

\begin{abstract}
With consumers as the drivers of continuous changers in the industry, decision-making has become extremely complex than ever. Every day, retailers are facing variety of difficult queries regarding the best course of action for their day to day businesses. Uncertainty became an important aspect of the retail business industry. Digitalization denotes continuous transformation need and importance for the retail sector. Based on previous research, the study simplifies how digitalization transforms these factors and identifies implications and proposals for the future study. Digitalization changes the following: the nature of retail offerings - blurred distinctions between products and services, what constitutes the actual offering and how it is priced; retail settings - where and when retailing takes place; and the factors who participate in retailing -retailers and consumers. The current transformation created challenges in research, where it demands sensitivity to development over time. This paper insists on significant and continuous transformation of retail sector and develops a framework that guides future research and aid retailers in analyzing retail sector's current transformation due to digitalization.
\end{abstract}

Keywords: Automation, Digitalisation, Retail, Consumers, retail-consumer interface.

\section{INTRODUCTION}

Retail store is sometimes referred to as a place of business owned and operated by a retailer but however generally owned and operated by a manufacturer or somebody apart from a merchant in which merchandise is sold primarily to final consumers. There are many varieties of stores, each store is different from the other one in terms of product assortment, service level and price level.

Before the computerization in retail sale sector, the store manager was in charge of all aspects of running a retail store, including deciding which items to be kept in stock, how to charge for the items in stock along with the management of the employees. For running a successful and profitable retail store, hard work and clever thinking of stores manager is always must.

Computerization is changing the way of business where it could accurately predict the demand and requirements of the business. With the help of computers, ordering of stock is automatic, IT supports the growth of large business to a great extend and each business has access to different technologies, and therefore they all have the equal opportunity to grow.

All businesses are relying on computers for the automation of traditional ways of their business operations. Computerization allows every business to deal with its large database and improve their operation process to a great extend. Moreover, data records will aid as decision support system in the business decision making.

\section{REVIEW OF LITERATURE}

Review of literature is a crucial internal part of analysis. It helps to avoid the rediscovery of known facts and duplication of research works. Over and above, review of literature helps in taking decisions on variables that are taken for scrutiny in the new research reports. The articles, books journals, documents pertaining to the topic reviewed for the study are listed below:

Choudhary And Sharma, 2006- "Digitalization Piracy In Retailing" A manual accounting system requires an accountant or bookkeeper to post business transactions to the general journal, ledger and worksheet by himself. This process could be completed by using paper journals , ledger sheets and also by creating sheets in a computer program Excel. It is said to be manual because each transaction is entered into the system individually by a human being. A computerized accounting system allows the user to enter the transactions into the program once all accounts are updated and generated as per the requirement.

Dr. Nopdol Tumwattana, 2008-"Computerization For Retail Business: Success Of The Body Glove" - Right from the introduction of computers to the general public for private, non-military use, people had profit motive and was thinking of various ways to use them for profit .

Huddleston, Whipple, Mattick, And Lee, 2009 "Customer Satisfaction In Automation; Specialty" - In their study conducted on United States households, compared customer perceptions related to satisfaction with conventional grocery stores to specialty grocery stores. The study analyzed the attributes of product assortment, price, quality and service in order to understand which attribute impacts more on store satisfaction for each store type. The results showed that perception of satisfaction were higher among specialty grocery store consumers compared to traditional grocery store consumers.

Verma \& Madan, 2011 - "Store Image and Automation"In a study conducted in Indian context highlighted that retailers are providing newer service dimensions to form distinctive searching experiences for the purchasers. However, whether or not customers are ready to understand newer service dimensions and obtaining affected for store patronage in new store formats or not, remains to be found out. The study attempted to seek out the key factors that are perceived as necessary to Indian shoppers in evaluation of a retail format.

Revised Manuscript Received on September 14, 2019.

Mrs.S.Akhila, Assistant Professor, Department of Commerce BPS \& CM, Sri Krishna Arts \&Science College Coimbatore, Tamilnadu, India. 
C. Robert Mcbrier, 2011 - "Impact Of Computers On Retailing"- The study examines the relationships between the intensity of IT investment and performance impact measures relating to computerization. Data were collected through a questionnaire survey of the retail industry in Singapore. Results express that the depth of IT investment has negligible relationships with information quality and improvement in work settings. Improvement in work settings is said to organizational impact however not to managerial satisfaction. Implications of the findings are discussed.

\section{STATEMENT OF THE PROBLEM}

Today's retail scenario insists on regular innovation in order to meet the earning and aspirations of ever demanding customers. Hence retailers need to roll out new products and services quickly and effectively using the latest technological equipment. Retail industry, no doubt, with the use of latest technology and adoption of digitalization in maintaining the records and data, they could render quality services to their customers.

Though, customers are enjoying the benefits of digitalization in retail sector in one aspect, they are also facing some problems during their interaction with the machines. Here the main problem of this survey is to know the various factors which are essential and important to know the need of digitalization in retail which will make the retailing process easier. This project is about the automation and digitalization of retail stores and to analyze its impact on the industry.

\section{OBJECTIVES OF THE STUDY}

To identify the answer for questions raised above, the following objectives were framed for the study,

$>\quad$ To study about the awareness of digitalization in retail stores.

To know the automated service rendered by the retailers in retail shops.

$>\quad$ To identify the challenges faced by the retailers in lack of technology.

$>\quad$ To analyze the satisfaction level of retailers using the computerization

\section{METHOD OF DATA COLLECTION}

Primary data is collected using a structured questionnaire prepared based on objectives of this study. Questions are framed on the basis of descriptive format. Face to face interview also conducted in order to improve data efficiency.

\section{TECHNIQUE OF DATA COLLECTION}

Collection was done using random sampling. In the first phase all respondents were briefed about how to fill up the questionnaire in the scale. The questionnaires were distributed to respondents. Filled questionnaires were collected from respondents for statistical analysis of data.

\section{SAMPLE SIZE}

Refers to the number of respondents to constitute a sample. It comprises of 200 respondents from Coimbatore city spread across various socio-demographic profiles.

\section{SAMPLE UNIT:}

In the present study a sample of respondents was randomly drawn from the population. Respondents are retailers.

\section{DATA ANALYSIS}

The primary data collected from the potential respondents i.e. retailers, which is properly sorted, classified, edited,

tabulated in proper format and analyzed by applying appropriate statistical tools.

The following statistical tools were used for analyzing the data:

(i) Percentage analysis

(ii) Chi-square tests

Percentage analysis: Percentage analysis is used to analyze the frequency distribution of sample respondents against the awareness of retailers towards the digitalization of retail stores in Coimbatore city.

\section{Table 1.1: Age Group Of The Respondents}

\begin{tabular}{|c|c|c|c|}
\hline S.No & $\begin{array}{c}\text { Age of } \\
\text { respondents }\end{array}$ & $\begin{array}{c}\text { No of } \\
\text { Respondents }\end{array}$ & Percent \\
\hline 1 & Up to 25 & 58 & 29 \\
\hline 2 & $26-30$ & 72 & 36 \\
\hline 3 & $31-50$ & 59 & 29.5 \\
\hline 4 & More than 50 & 11 & 5.5 \\
\hline & Total & 200 & 100 \\
\hline
\end{tabular}

It is clear from the above table, Out of the total respondents taken for the study $29 \%$ of respondents belong to the age group of below 25 years, $36 \%$ of respondents belong to the age group of 26-30 years, $29.5 \%$ of respondents belong to the age group of $31-50$ and $5.5 \%$ of respondents belong to the age group of above 50 years.

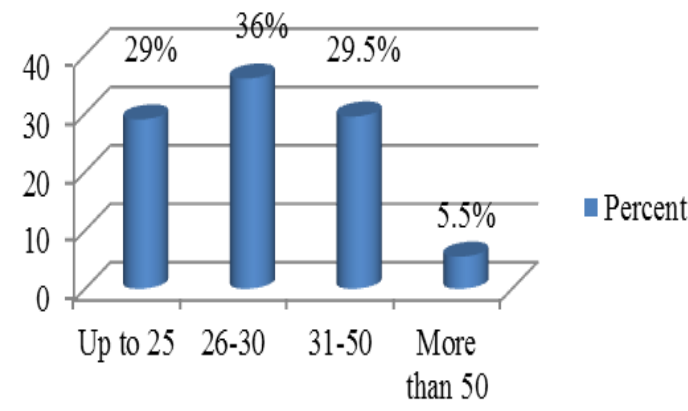

Hence, Most $(36 \%)$ of respondents belong to the age group between 26 to 30 years. 
Table 1.2: Educational Qualification Of The Respondents

\begin{tabular}{|c|c|c|c|}
\hline S.No & $\begin{array}{c}\text { Education } \\
\text { qualification }\end{array}$ & $\begin{array}{c}\text { No of } \\
\text { Respondents }\end{array}$ & Percent \\
\hline 1 & H.S.C & 23 & 11.5 \\
\hline 2 & Diploma & 24 & 12 \\
\hline 3 & Under Graduate & 73 & 36.5 \\
\hline 4 & Post Graduate & 48 & 24 \\
\hline 5 & Professional & 32 & 16 \\
\hline & Total & 200 & 100 \\
\hline
\end{tabular}

It is clear from the above table, Out of the total respondents taken for the study, $36.5 \%$ of the respondents are under graduates, $24 \%$ of the respondents are post graduates, $16 \%$ of the respondents are professionals, $12 \%$ of respondents are Diploma holders, and $11.5 \%$ of respondents are having HSC qualifications.

Hence, Most (36.5\%) of respondents are under graduates.

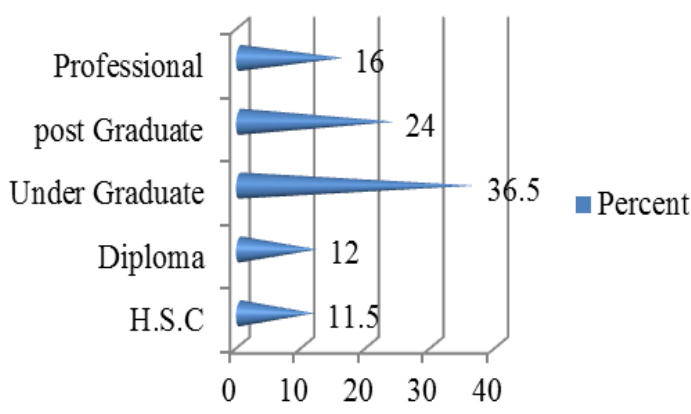

Table 1.3: Awareness About Digitalization In Retail Stores

\begin{tabular}{|c|c|c|c|}
\hline S.No & $\begin{array}{c}\text { Use } \\
\text { Computerized } \\
\text { Accounting }\end{array}$ & $\begin{array}{c}\text { No of } \\
\text { Respondents }\end{array}$ & Percent \\
\hline 1 & Yes & 127 & 63.5 \\
\hline 2 & No & 73 & 36.5 \\
\hline & Total & 200 & 100 \\
\hline
\end{tabular}

It is clear from the above table, Out of the total respondents taken for the study, $63.5 \%$ of the respondents are aware about the digitalization in retail stores and the balance of retailers of $36.5 \%$ of the respondents are not aware about the digitalization in retail stores

Hence, Majority $(63.5 \%)$ of respondents are aware about the digitalization in retail stores.

Table 1.4: Digitalized Retail Store

\begin{tabular}{|c|c|c|c|}
\hline S.No & $\begin{array}{c}\text { Run digitalized } \\
\text { retail store }\end{array}$ & $\begin{array}{c}\text { No of } \\
\text { Respondents }\end{array}$ & Percent \\
\hline 1 & Yes & 122 & 61 \\
\hline 2 & No & 78 & 39 \\
\hline & Total & 200 & 100 \\
\hline
\end{tabular}

It is clear from the above table, Out of the total respondents taken for the study, $61 \%$ of the respondents run digitalized retail store and $39 \%$ of respondents doesn't have digitalized retail store.

Hence, Majority (61\%) of respondents run digitalized retail store.

Table 1.5: Challenges Faced Before Digitalization

\begin{tabular}{|c|c|c|c|}
\hline S.No & $\begin{array}{c}\text { Challenges } \\
\text { Faced }\end{array}$ & $\begin{array}{c}\text { No of } \\
\text { Respondents }\end{array}$ & Percent \\
\hline 1 & $\begin{array}{c}\text { Lack of man } \\
\text { power }\end{array}$ & 89 & 44.5 \\
\hline 2 & $\begin{array}{c}\text { Lack of use of } \\
\text { tools }\end{array}$ & 64 & 32 \\
\hline 3 & $\begin{array}{c}\text { Misaligned } \\
\text { category }\end{array}$ & 29 & 14.5 \\
\hline 4 & Others & 18 & 9 \\
\hline & Total & 200 & 100 \\
\hline
\end{tabular}

It is clear from the above table, Out of the total number of respondents $44.5 \%$ of the retailers faced the problem of lack of man power before the digitalization of retail store, $32 \%$ of the retailers faced the problem of lack of use of tools in their stores and $14.5 \%$ of the retailers faced misaligned category issues and $9 \%$ of the retailers faced other issues like mishandling the account details, frauds etc

Hence, Majority $(44.5 \%)$ of the retailers faced the problem of lack of man power before the digitalization of retail store.

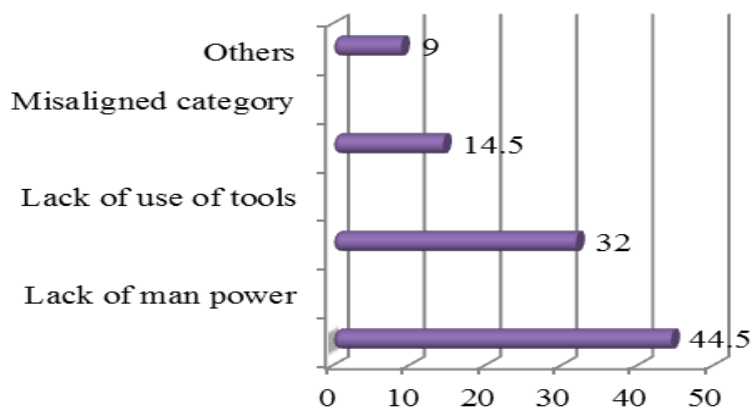

Table 1.6: Reason For Computerizing The Retail

\begin{tabular}{|c|l|c|c|}
\hline S.No & \multicolumn{1}{|c|}{ Reason } & $\begin{array}{c}\text { No of } \\
\text { Respondents }\end{array}$ & Percent \\
\hline 1 & Time savings & 91 & 45.5 \\
\hline 2 & $\begin{array}{l}\text { Ensures } \\
\text { accuracy }\end{array}$ & 52 & 26 \\
\hline 3 & Consistency & 38 & 19 \\
\hline 4 & $\begin{array}{l}\text { Reduces the } \\
\text { risks of fraud }\end{array}$ & 19 & 9.5 \\
\hline & Total & 200 & 100 \\
\hline
\end{tabular}


It is clear from the above table, Out of the total number of respondents $45.5 \%$ of the retailers computerize their stores to save time, $26 \%$ of the retailers computerize their stores because they think it ensures accuracy, $19 \%$ of the retailers computerize their stores for consistency in transactions they process, $9.5 \%$ of the retailers computerize their stores to reduce the risk of frauds.

Hence, Majority (45.5\%) of the retailers computerize their retail store as it helps in time saving.

CHI SQUARE TESTS: It is applied to test the association between demographic factors like age, educational qualification of consumers and opinion of them regarding digitalization of retail stores.

\section{Hypothesis:}

The following hypothesis has been framed to find out relation between overall satisfaction and socio-economic profile of respondents.

Hypothesis 1: There is no relationship between gender and digitalization of retail stores.

Hypothesis 2: There is no relationship between age and services rendered by the retailers.

Hypothesis 3: There is no relationship between educational qualification and awareness level of digitalization of retail stores.

Hypothesis 4: There is no relationship between the term of retail store and the challenges faced by the retailers.

Hypothesis 5: There is no relationship between educational qualification and the satisfaction level of retailers in digitalizing the retail store.

Table 1.7

\begin{tabular}{|c|l|c|c|c|c|}
\hline $\begin{array}{c}\text { S. } \\
\text { No }\end{array}$ & Variables & $\begin{array}{c}\text { Degr } \\
\text { ee of } \\
\text { freed } \\
\text { om }\end{array}$ & $\begin{array}{c}\text { Table } \\
\text { value }\end{array}$ & $\begin{array}{c}\text { Chi- } \\
\text { Squa } \\
\text { re } \\
\text { value }\end{array}$ & Significance \\
\hline 2 & $\begin{array}{l}\text { Gender and } \\
\text { digitalization } \\
\text { of retail } \\
\text { stores }\end{array}$ & 3 & 7.81 & 5.23 & $\begin{array}{c}\text { Not } \\
\text { significant }\end{array}$ \\
\hline 3 & $\begin{array}{l}\text { Age and } \\
\text { services } \\
\text { rendered by } \\
\text { the retailers }\end{array}$ & 9 & 16.92 & 11.63 & $\begin{array}{c}\text { Not } \\
\text { significant }\end{array}$ \\
\hline & $\begin{array}{l}\text { Educational } \\
\text { qualification } \\
\text { and } \\
\text { awareness } \\
\text { level of } \\
\text { digitalization } \\
\text { of retail } \\
\text { stores. }\end{array}$ & 12 & 21.03 & 31.67 & Significant \\
\hline 5 & $\begin{array}{l}\text { Term of } \\
\text { retail store } \\
\text { and the } \\
\text { challenges } \\
\text { faced by the } \\
\text { retailers. }\end{array}$ & 12 & 26.30 & 16.32 & significant \\
\hline \multirow{2}{*}{$\begin{array}{l}\text { Educational } \\
\text { qualification } \\
\text { and the } \\
\text { satisfaction } \\
\text { level of } \\
\text { retailers in } \\
\text { digitalizing } \\
\text { the retail } \\
\text { store. }\end{array}$} & 12 & 21.03 & 29.46 & Significant \\
\hline
\end{tabular}

\section{FINDINGS \& RESULTS}

The following are some of the important findings of this study

$>$ Majority (36\%) of the respondents were in the age Group between 26-30 years.

$>$ Majority $(36.5 \%)$ of the respondents were under graduates.

$>$ Majority $(63.5 \%)$ of the respondents are aware about digitalization in retail stores.

$>$ Majority (61\%) of the respondents run digitalized retail store.

$>$ Majority (44.5) of the respondents faced the problem of lack of man power before the digitalization of retail store.

$>\quad$ Majority (45.5\%) of the respondents use digitalized retail store for time saving.

$>\quad$ There is no significant relationship between gender and digitalization of retail stores.

$>$ There is no significant relationship between age and services rendered by the retailers

$>$ There is a significant relationship between educational qualification and awareness level of digitalization of retail stores.

$>\quad$ There is no significant relationship between term of retail store and the challenges faced by the retailers.

$>$ There is a significant relationship between educational qualification and the satisfaction level of retailers in digitalizing the retail store.

\section{SUGGESTIONS}

$>\quad$ The computerized system should be more user friendly to the retailers.

$>\quad$ In spite of having digitalized retail store, to retain and to attract more customers, retailers need to continue with the services like after sale delivery and cash credit.

$>$ Retailers should use cost effective technologies such as SMS, E-Mail, etc. To get personal touch with customers.

There are still some retailers who are not having any idea about the computerized systems, awareness on digitalization must be created among the retailers for them to compete with the digitalized environment.

\section{CONCLUSION}

Now days, due to increase in competition, customer satisfaction is considered to be the most important thing in retail industry. So the retailers are in the position to adapt to the technology to change the way of service to attract customers and increase their satisfaction level.

An improvised retail store is not affecting the traditional store as the majority of the consumers are of the opinion that they always visit Kirana stores inspite of the existence of computerized stores. They strongly agree on coexistence of both modern and traditional retail stores. The growth of computerized markets is much slower in India when compared to other neighboring countries and the 
development of the retails sector depends on the regulatory and structural constraints.

Government should concentrate more on supporting the retail sector with regards to the challenges faced by them. Only then a rapid growth of organized retail store is possible to a great extend in India.

\section{REFERENCES}

1. BBC - GCSE Bitesize: Computerisation of retail

2. Computerization of Book Store - Kurukshetra.nic.in

3. The Art Of Retailing (Book Only) - Page 79 - Google Books Result

4. Specialty shop retailing-Book by Carol L. Schroeder. 